\title{
The water footprint from hydroelectricity: a case study for a hydropower plant in Romania
}

\author{
Lăcrămioara Diana Robescu ${ }^{1, *}$, and Dana Andreya Bondrea $^{1}$ \\ ${ }^{1}$ University POLITEHNICA of Bucharest, Department of Hydraulics, Hydraulic Machinery and Environmental Engineering, \\ Romania
}

\begin{abstract}
In Romania, the hydropower is the main form of renewable source with an important share in energy mix. Despite their valuable advantages on supplying energy and balancing the energy system, public acceptance, environmental, social and economic impact has become a common challenge in development of hydropower projects. Increasing of water consumption and raising awareness regarding available water resources leads to an integrated management approach of them. In this paper the water footprint is estimated for one of the largest Romanian hydropower project, namely Hydropower Plant Vidraru. The water footprint from hydroelectricity is evaluated considering electricity production of the hydropower plant, water footprint of dam construction and three different approaches to quantify water footprint of the reservoir: gross water consumption, net water consumption and water balance. Also, water footprint is assessed based on economic value of the reservoir using allocation coefficients for various purposes of the reservoir. It is estimated that economic benefit of the reservoir is $81.92 \cdot 10^{6} € / \mathrm{y}$, with hydroelectricity major contributor.
\end{abstract}

\section{Introduction}

The evolution towards modern society leads to increasing of the water consumption. Thus, because of limited water resources the available ones have started to decrease and many regions experience water stress. Freshwater has almost always been used in human activities regardless of the quantity and without considering the environmental impact. It is found that the global consumption of freshwater resources has increased six times in the last century [1].

To have an indicator for water consumption, it was introduced the concept of water footprint (WF) [2]. The water footprint considers the volume of freshwater consumed and polluted to realize a product along its supply chain, [3], considering a life-cycle assessment perspective. WF is recommended by some authors to be a component in evaluation of newly project proposals for hydropower plants, [4].

Due to increasing of population and the level of life, the demand for energy is rising fast. International Energy Agency (IEA) predicts that the global energy needs expand by $30 \%$ until 2040, [5]. All countries have faced the challenge to provide secure, affordable and environmentally friendly energy. Water is used both in primary energy production and in power generation. Water-energy nexus and also water-energyfood nexus are well-known, and they have been subject of many studies.
Hydropower is one of the oldest sources of energy, an efficient and clean technology, providing 19\% of the global electricity $[6,7]$. It is found to be the most sustainable renewable energy after the wind power, [8], representing the largest contributor in electricity mix in Romania, after energy produced from coal $[9,10]$, and the leader for electricity produced from renewables. In Romania it supplied $95.83 \%$ of all renewable electricity in 2017 and at global level it supplied $71 \%$, respectively $16.4 \%$ of energy produced from all sources, [11, 12]. Moreover, hydropower offers advantage of flexibility, providing energy on demand, both base-load and peaking power, balancing the energy system.

Despite its advantages related to energy generation and the lowest lifecycle GHGs emission per kilowatt hour after wind energy, [12], there are concerns regarding social, economic and environmental impact.

In this regard, The International Hydropower Association (IHA) launched in 2011 The Hydropower Sustainability Assessment Protocol, as a framework of assessment hydropower projects at different stages, [12]. In 2018 this Protocol is expanded to cover carbon footprint and resilience to climate change. Before of IHA actions, IEA Hydropower Implementing Agreement made and updated recommendations on hydropower and environment, [13, 14].

Recognizing the significant role of hydropower to the implementation of the Renewable Energy Directive and to achieve the EU energy targets for 2020-2030,

\footnotetext{
* Corresponding author: diana.robescu@upb.ro
} 
European Commission releases in 2018 a document on the requirements for hydropower in relation to EU Nature, [15].

On the other hand, hydropower is one of the largest water consuming sectors, mainly because of the evaporation from the reservoir surface created by the dams to capture large volumes of water. But there are many debates about this.

Using gross evaporation approach to assess the WF it is estimated that hydropower has the largest WF comparing with those for electricity from wind, solar and geothermal energy [16-18].

Assumption that WF from hydroelectricity is equal with WF of reservoir leads to various debates. It should recognize that land surfaces consumed water through evapotranspiration previously the hydropower plant construction. So, this quantity should be subtracted from gross evaporation, resulting in a lower WF, [19, 20], even close to zero, [21]. Furthermore, there are seasonal variations of volumes of water stored in lake. Based on both previous considerations, a novel approach for WF assessment is released and reveals that mostly of the previous studies overrate WF from hydroelectricity, [22].

Using net water balance to estimate the WF, considering both water inputs and outputs from the reservoir, results in WF negative values, indicate that reservoirs in high rainfall areas can collect more water than they lose through evaporation, [19].

Taken into consideration that WF concept is intended to show a change in the volume of water appropriated for a certain purpose, and therefore not available for another purpose, it is concluded that the right approach should be applied according to the aim of the study: gross evaporation approach is suitable for WF assessment and net evaporation approach for analysing changes in hydrology, [23].

Usually the water reservoir of the hydropower plant has various other purposes, not only to generate hydroelectricity. Considering the most recent publication of the World Register of Dams, irrigation is the most common purpose of dams, followed by hydropower, water supply, flood control, recreation, navigation and fish farming, [24]. Allocating the total WF among the ecosystem services and setting an allocation coefficient indicate a better approach for calculation of WF from hydroelectricity for Three Gorges Reservoir, separating WF for hydropower from $\mathrm{WF}$ for reservoir, [25]. Attributing WF to purposes, based on economic value, shows that hydroelectricity has the largest share in the total WF, followed by residential and industrial water supply, resulting a global average WF of hydroelectricity of $14.6 \mathrm{~m}^{3} \mathrm{GJ}^{-1}$ [26].

In the current study the WF for the Vidraru Hydroelectric Power Plant, a storage hydropower plant on the Arges River, Romania, Figure 1. It was commissioned in 1966, the double-arched concrete dam Vidraru being the $5^{\text {th }}$ of the greatest in Europe and the $9^{\text {th }}$ in the world at that time. It is the second largest artificial lake in Romania, located in a picturesque mountainous area, crossing point to Transfagarasan. The reservoir has a total volume of $465 \mathrm{Mm}^{3}$, allowing the capture of $19.7 \mathrm{~m}^{3} / \mathrm{s}$ from Arges River and from several tributaries, from a $745 \mathrm{~km}^{2}$ water catchment area. The total area of the lake is 870 ha, [26]. Vidraru hydropower plant has an installed capacity of $220 \mathrm{MW}$ (4 Francis turbines, $55 \mathrm{MW}$ each of them) and can produce approximately $400 \mathrm{GWh}$ of electricity in an average hydrological year $[27,28]$.

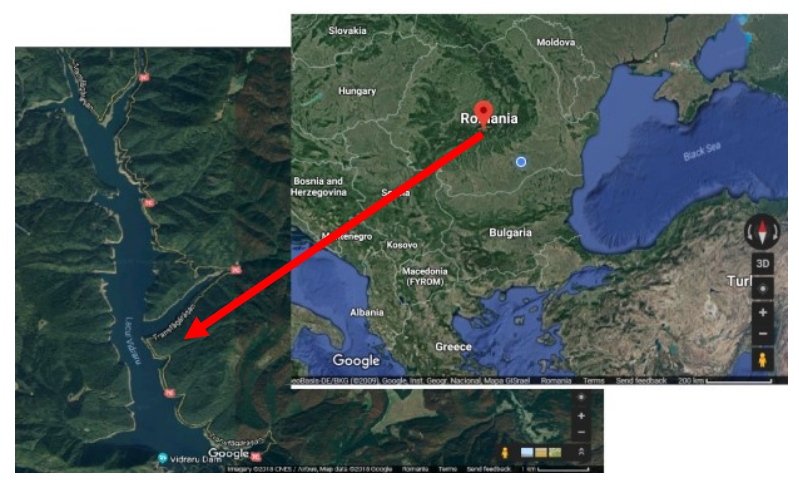

Fig.1. Location of the Lake Vidraru, Romania (Source: https://www.google.ro/maps).

\section{Methodology and data}

The $W F$ of electricity generated by Vidraru Hydropower Plant is calculated for year 2017 by dividing WF of the reservoir to annual energy production:

$W F_{H}=\frac{W F_{R}}{E G},\left[\mathrm{~m}^{3} / \mathrm{GJ}\right]$

where $W F_{R}$ is the quantity of water footprint of the reservoir $\left[\mathrm{m}^{3} / \mathrm{y}\right]$ and $E G$ is the annual energy production $[\mathrm{GJ} / \mathrm{y}]$.

The blue WF of the reservoir includes operational and supply chain part, [18], [26]. It is the sum of WF related to evaporation from the surface of the reservoir, $W F_{\text {evap }}$, and WF related to the dam construction $W F_{d c}$, [18]:

$W F_{R}=W F_{\text {evap }}+W F_{d c},\left[m^{3} / y\right]$

WF related to evaporation is estimated using three approaches: gross water consumption, net water consumption and water balance approach method.

\subsection{Gross water consumption approach}

The dominant calculations of WF of hydroelectricity use gross evaporation, [29], based on the methodology described in details in $[4,30]$ :

$$
W F_{\text {evap }, g}=W E,\left[\mathrm{~m}^{3} / \mathrm{y}\right]
$$

where $W E$ is the total volume of evaporated water from the reservoir in one year that depends on the quantity of water evaporated daily during a year and the area of the reservoir.

The total volume of evaporated water from the hydropower reservoir in one year is, [26]:

$$
\mathrm{WE}=\mathrm{k} \cdot\left(10 \times \sum_{\mathrm{t}=0}^{365} \mathrm{E}\right) \cdot \mathrm{A},\left[\mathrm{m}^{3} / \mathrm{y}\right]
$$


where $E$ - daily evaporation, [mm/day], A - area of the reservoir, [ha], $k=0.5625$ - area correction factor, that takes into account that the reservoir surface at average filling conditions is smaller than the maximum area reported in the databases and 10 is a constant used to convert $\mathrm{mm}$ into $\mathrm{m}^{3} \mathrm{ha}^{-1}$.

The evaporation from water surface, $E$, is estimated with the Penman - Monteith equation, [4]:

$$
\mathrm{E}=\frac{1}{\lambda} \cdot \frac{\Delta_{\mathrm{w}} \cdot\left(R_{n}-G\right)+\gamma \cdot \mathrm{f}(\mathrm{u}) \cdot\left(\mathrm{e}_{\mathrm{w}}-e_{a}\right)}{\Delta_{\mathrm{w}}+\gamma},
$$

where $\lambda$ - the latent heat of vaporization, $\Delta_{w}$ - the slope of the temperature saturation water vapour curve at water temperature $\left[\mathrm{kPa} /{ }^{\circ} \mathrm{C}\right], R_{n}$ - net radiation [MJ $\left.\mathrm{m}^{2} d a y^{-1}\right], G$ - the change in heat storage in the water $\left[\mathrm{MJ} / \mathrm{m}^{2} / \mathrm{day}\right], f(u)$-the wind function $\left[\mathrm{MJ} / \mathrm{m}^{2} / \mathrm{day} / \mathrm{kPa}\right], e_{w}$ - the saturated vapour pressure at water temperature $[\mathrm{kPa}], e_{a}$ - the vapour pressure at air temperature $[\mathrm{kPa}]$ and $\gamma$ - the psychometric constant $\left[\mathrm{kPa} /{ }^{\circ} \mathrm{C}\right]$.

The data for the air temperature, the wind speed and the cloud cover for Vidraru area are retrieved from the meteorology archive Meteoblue [31]. This weather archive shows simulation data, not measured data.
For the average air temperature $\left[{ }^{\circ} \mathrm{C}\right]$ it is used the national climate monitoring data from National Meteorological Administration, [32]. Meteorological data recorded on the Vidraru area are shown in Figure 1,2 and 3 .

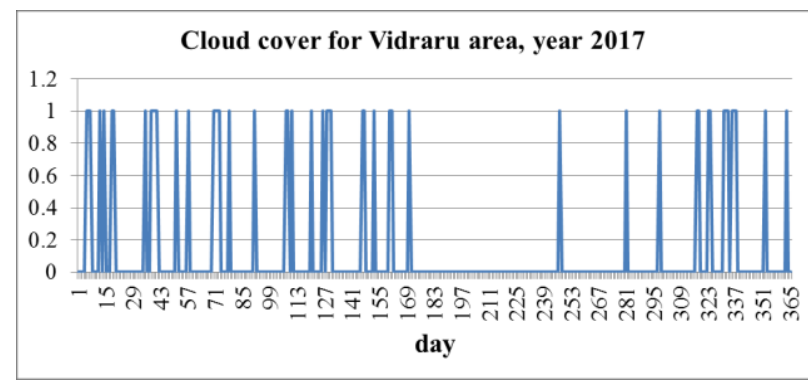

Fig.2. Daily variations of cloud cover for Vidraru area.

The daily average condensation temperature for each month is obtained using Dew Point Calculator, [33]. The Dew Point Calculator uses day temperature (T) and relative humidity $(\mathrm{RH})$ to calculate the condensation temperature. Data calculated for year 2017 are presented in Figure 3.

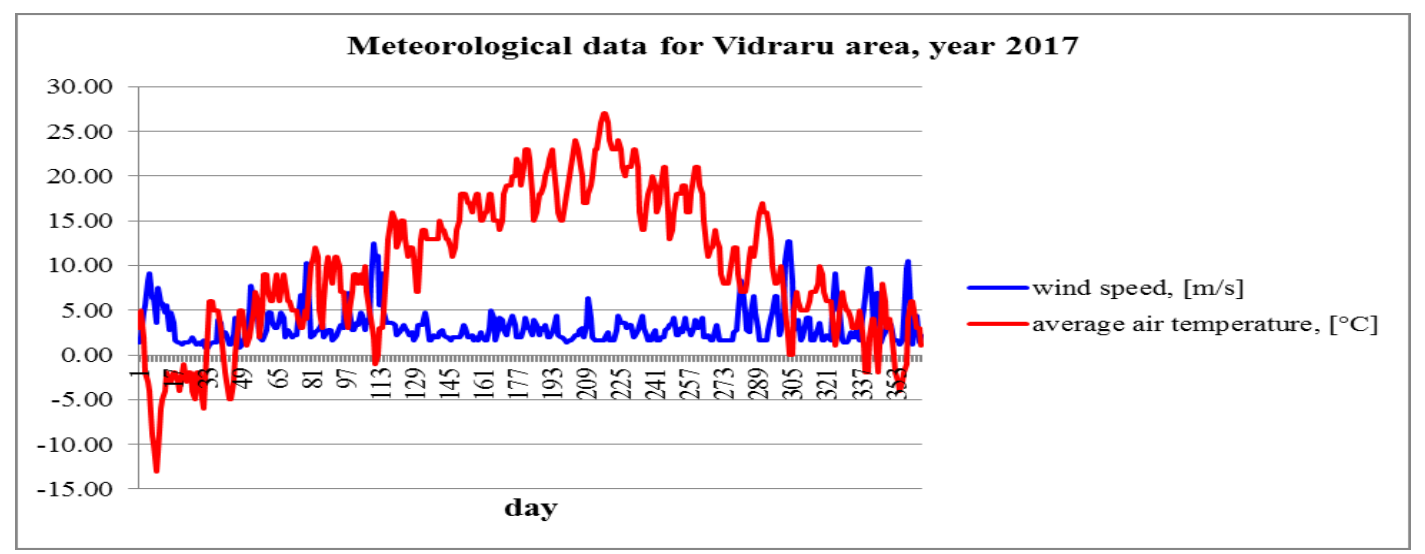

Fig.3. Daily variations of meteorological data for Vidraru area.

The average temperature at the surface of the lake is considered equal to the average air temperature in that month. Although it is normal to have temperature variations at the surface of the lake, the average of these temperatures can be considered equal to the air for such a large area as Lake Vidraru.

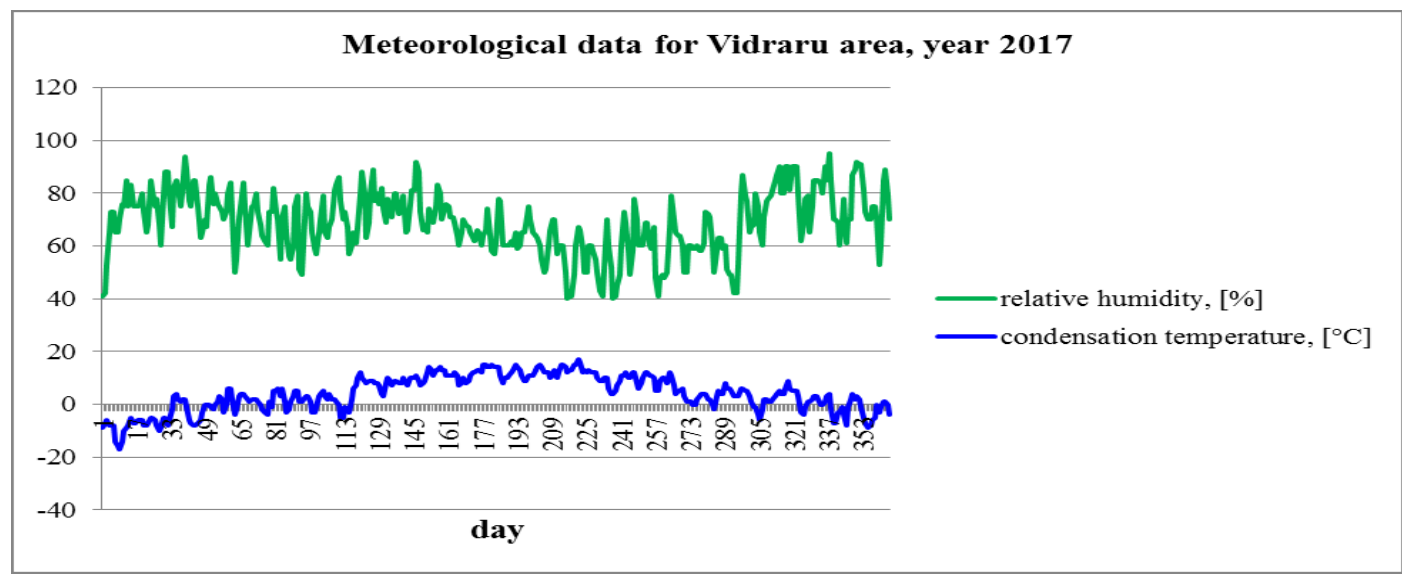

Fig.4. Daily variations of relative humidity and condensation temperature. 


\subsection{Net water consumption approach}

In this approach it is considered that before the dam the area was covered by vegetation and WF of the reservoir is given by the relation:

$$
W F_{\text {evap }, n}=W E-W E_{t r},\left[\mathrm{~m}^{3} / \mathrm{y}\right]
$$

where $\mathrm{WE}_{\mathrm{tr}}$ is evapotranspiration of the flooded area, $\left[\mathrm{m}^{3} / \mathrm{y}\right]$, that is the quantity of water evaporated before the existence of the dam.

Many authors consider it more appropriate for the calculation of the real water consumption by hydropower, [20-22, 34-36].

The challenge in this approach is to calculate evapotranspiration. In this study it is assumed that area before the dam construction was covered only with conifers and deciduous species forest. Evaporation in the forest is a complicated physical process that includes transpiration by the green mass of the tree crowns, evaporation from the soil and by ground vegetation and evaporation of intercepted precipitation. In order to evaluate each kind of evaporation different techniques are applied, [36].

There are many models used to calculate evapotranspiration, some of the synthetized in [37].

In this paper the real annual evapotranspiration of the flooded area is calculated using Turc formula, based on temperature and precipitation, [38]:

$$
E_{r a}=\frac{X}{\sqrt{0.9+\frac{X^{2}}{L^{2}}}},[\mathrm{~mm} / \mathrm{y}]
$$

where $\mathrm{X}$ - annual precipitation, [mm/y] and

$$
L=300+25 \cdot T_{m}+0.05 \cdot T_{m}{ }^{2},[\mathrm{~mm} / \mathrm{y}]
$$

where $T_{m},\left[{ }^{0} \mathrm{C}\right]$,is the average annual air temperature that is calculated as an average weighted with monthly precipitation $\mathrm{X}_{\mathrm{i}}(\mathrm{i}=1,2, \ldots 12),[\mathrm{mm}]$ :

$$
T_{M}=\frac{X_{1} \cdot T_{1}+\ldots+X_{12} \cdot T_{12}}{X_{1}+\ldots+X_{12}},\left[{ }^{0} \mathrm{C}\right]
$$

The data are retrieved from the meteorology archive Meteoblue [31] and are shown in Figure 4.

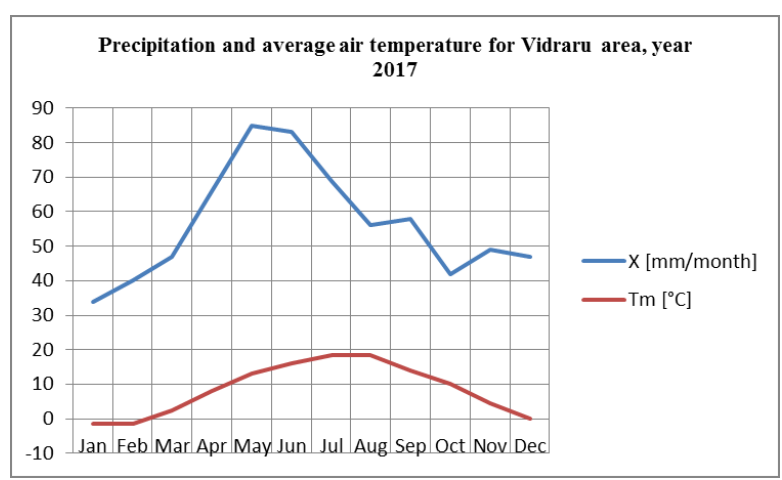

Fig.5. Monthly precipitation and average air temperature.
Evapotranspiration of the flooded area is:

$\mathrm{WE}_{\mathrm{tr}}=E_{\mathrm{ra}} \cdot \mathrm{A},\left[\mathrm{m}^{3} / \mathrm{y}\right]$

\subsection{Net water balance approach}

In this method, WF of the reservoir is calculated considering net loss of water given the input, rainfall, and the output, evaporation, of the reservoir:

$$
W F_{\text {evap }, n w b}=W E-k \cdot R,\left[\mathrm{~m}^{3} / \mathrm{y}\right]
$$

where $R$ - the annual volume of rainfall falling on the reservoir, $\left[\mathrm{m}^{3} / \mathrm{y}\right]$. The data are estimated from Figure 4.

Water losses through seepage are neglected, because they aren't really losses, being available downstream, [39, 40].

\subsection{WF related to the dam construction}

$\mathrm{WF}_{\mathrm{dc}}$ is related mainly on the construction material of the dam. Vidraru dam is double-arched concrete dam, with a height of $166.6 \mathrm{~m}$ and a crest length of $307 \mathrm{~m}$, [27]. $\mathrm{WF}_{\mathrm{dc}}$ is calculated considering a mixture of $1 \%$ unalloyed steel, 29\% Portland cement and 70\% aggregates, [26], with WF for unalloyed steel $11.8 \mathrm{l} / \mathrm{kg}$ and WF for Portland cement $2.2 \mathrm{l} / \mathrm{kg}$, [41], respectively WF for aggregates $0.001 \mathrm{~m}^{3} / \mathrm{kg}$, [42].

\subsection{Allocation WF to the purpose of the lake}

The lake Vidraru is a complex one. It has multiple services, but mainly of them is hydroelectric generation. Other uses are flood control, recreation, irrigation and water supply.

The water footprint considering different purposes of the lake can be calculated as, [26]:

$$
W F_{A, i}=W E \cdot \eta_{i}
$$

where $\eta_{i}$ is allocation coefficient:

$\eta_{i}=V_{i} / V$

$V_{i}$ - economic value of purpose $i[€ / \mathrm{y}]$ and $V$ - total economic value of all services, $[€ / \mathrm{y}]$.

Hydroelectricity generation

The economic value of hydroelectricity generation [Euro/yr] is calculated using market valuation method, by multiplying the mean annual electricity generation [GWh/yr] with the economic value of electricity [Euro/ $\mathrm{GWh}$, [26]. It is considered electricity price of $0.13 € / \mathrm{kWh},[43]$, and mean annual energy production $400 \mathrm{GWh} / \mathrm{y}$.

Recreation

Lake Vidraru is crossing point to Transfagarasan, road open from $1^{\text {st }}$ of July to $30^{\text {th }}$ of October with many numbers of tourists every year, being one of the main Romanian touristic attractions. Recreation value of the lake is calculated based on the number of travellers and travel cost/day, [25]. Due to the lack of information 
regarding tourism in the studied area, it was estimated 0.5 million of travellers each year in Vidraru area, starting from the fact that approximately 2 million tourist visited Bucharest in 2017, [44]. No official information is found for travel cost, so that it is estimated at 200 lei/day that is around $45 € /$ day, [45].

Flood control storage

The economic value of flood control storage, [€/y], is calculated by multiplying the available flood storage volume $\left[\mathrm{m}^{3}\right]$ with the economic value of flood storage, [26]. Available flood storage volume of the lake is 25 $\mathrm{Mm}^{3}$, [46]. For lack of data regarding economic value of flood storage, not only in Romania, but in the literature, it is estimated $0.117 \mathrm{USD} / \mathrm{m}^{3} \cdot \mathrm{y}$, [26], that is $0.1 \mathrm{Euro} / \mathrm{m}^{3} \cdot \mathrm{y}$.

\section{Results and discussion}

In order to process all the data, a $\mathrm{C}++$ application was developed.

Evaporation from the reservoir in a year results $1135.69 \mathrm{~mm} / \mathrm{y}$ that corresponds to the total volume of water evaporated $W E=5.56 \cdot 10^{6}\left[\mathrm{~m}^{3} / \mathrm{y}\right]$.

Using relation (7) and data shown in Figure 4, real annual evapotranspiration results $E_{r a}=437.34 \mathrm{~mm} / y$.

Average annual evaporation of a mature forest of different types of conifers with the age of 100 to 120 years and different deciduous species with the age of 50 to 60 years, located in the southern taiga zone in URSS, is estimated as $490[\mathrm{~mm} / \mathrm{y}]$ for spruce, 450 $[\mathrm{mm} / \mathrm{y}]$ for pine and $585[\mathrm{~mm} / \mathrm{y}]$ for deciduous (birch and aspen), [36].

Analysing evapotranspiration in Romania from 1961 to 2013 it was found that between altitude of 250 and 500 meters evapotranspiration varies in the range 400 - $600 \mathrm{~mm} / \mathrm{y}$, and above 1250 meters' evapotranspiration falls below $400 \mathrm{~mm} / \mathrm{y}$, [47].

It can be observed that the value resulted in this study is approximately in the range of data found by other authors.

Based on monthly precipitation (Figure 4), annual precipitation $X$ is $676[\mathrm{~mm} / \mathrm{y}]$, conducting to the annual volume of rainfall falling on the reservoir $R=3.31 \cdot 10^{6}$ $\left[\mathrm{m}^{3} / y\right]$.

The WF for the dam construction in this study is $W F_{d c}=0.197 \cdot 10^{6} \mathrm{~m}^{3} / y$, assuming typical lifespan of the dam 100 years, [26], and the total volume of concrete $480000 \mathrm{~m}^{3}$ that are used for the dam construction it was used of concrete, [27]. It can be noted a much lower value than those resulted from evaporation or evapotranspiration. However, it is not taken into account in this study the water consumption and fuel use during dam construction, and also grey WF.

WF for the reservoir, $W F_{R}$, and corresponding values for WF from hydroelectricity considering three approaches and the mean annual energy production 400 GWh are presented in Table 1.

Table 1. The water footprint of the reservoir, $\left[10^{6} \mathrm{~m}^{3} / \mathrm{y}\right]$.

\begin{tabular}{|c|c|c|c|c|}
\hline \multicolumn{2}{|c|}{ WFevap } & $\mathbf{W F}_{\mathbf{d c}}$ & $W_{R}$ & $\mathrm{WF}_{\mathrm{H}}$ \\
\hline $\mathrm{WF}_{\text {evap }, \mathrm{g}}$ & 5.56 & \multirow{3}{*}{0.196} & 5.76 & 4 \\
\hline $\mathrm{WF}_{\text {evap,n }}$ & 1.76 & & 1.96 & 1.36 \\
\hline $\mathrm{WF}_{\text {evap,nwb }}$ & 2.25 & & 2.45 & 1.7 \\
\hline
\end{tabular}

The total economic value of the lake Vidraru is hard to estimate because of the lack of data available. In this study, it results $81.92 \cdot 10^{6} € / y$, spawned by hydroelectricity generation, flood control and recreation. Note that it is based on the assumptions of most of the data. Table 2 summarizes the results, taken into account gross evaporation approach in the WF calculation for reservoir. Hydroelectricity generation represents the largest share of total WF.

Table 2. The water footprint of the reservoir, considering allocation WF to the purpose of the lake, $\left[10^{6} \mathrm{~m}^{3} / \mathrm{y}\right]$.

\begin{tabular}{|l|c|c|c|}
\hline \multicolumn{1}{|c|}{$\begin{array}{c}\text { Reservoir } \\
\text { purpose }\end{array}$} & $\begin{array}{c}\text { Economic } \\
\text { value } \\
{\left[\mathbf{1 0}^{\mathbf{6}} \boldsymbol{\epsilon} / \mathbf{y}\right]}\end{array}$ & $\begin{array}{c}\text { Allocation } \\
\text { coefficient } \\
\boldsymbol{\eta}[\mathbf{\%}]\end{array}$ & $\begin{array}{c}\text { WF/reservoir } \\
\text { purpose } \\
{\left[10^{6} \mathrm{~m}^{3} / \mathbf{y}\right]}\end{array}$ \\
\hline $\begin{array}{l}\text { Hydroelectricity } \\
\text { generation }\end{array}$ & 57.2 & 0.7 & 3.89 \\
\hline Recreation & 22.2 & 0.27 & 1.50 \\
\hline Flood storage & 2.5 & 0.03 & 0.17 \\
\hline
\end{tabular}

It is difficult to compare results with other reservoir because, besides water area of the reservoir, different meteorological data in the area affects WF. In Table 3 are indexed WFs for some hydropower plants [4, 40], with similar reservoir area or evaporation or installed capacity.

Table 3. The water footprint for different hydropower plants, based on gross evaporation approach.

\begin{tabular}{|c|l|l|l|l|l|}
\hline $\begin{array}{c}\text { Hydropower } \\
\text { plant }\end{array}$ & \multicolumn{1}{|c|}{ Country } & $\begin{array}{c}\text { Reservoir area } \\
{[\mathbf{h a}]}\end{array}$ & $\begin{array}{c}\text { Evaporation } \\
{[\mathbf{m m} / \mathbf{y}]}\end{array}$ & $\begin{array}{c}\text { Installed capacity } \\
{[\mathbf{M W}]}\end{array}$ & $\begin{array}{c}\text { WF } \text { for actual } \\
\text { energy production } \\
{\left[\mathbf{m}^{\mathbf{3}} / \mathbf{G J}\right]}\end{array}$ \\
\hline Lubuge & China & 400 & 1040 & 600 & 0.50 \\
\hline Waitaki & $\begin{array}{l}\text { South Island of New } \\
\text { Zealand }\end{array}$ & 622 & 1153 & 105 & 3.98 \\
\hline Arapuni & $\begin{array}{l}\text { North Island of New } \\
\text { Zealand }\end{array}$ & 883.2 & 844 & 196.66 & 2.57 \\
\hline Vidaru & Romania & $\mathbf{8 7 0}$ & $\mathbf{1 1 3 5 . 6 9}$ & $\mathbf{2 2 0}$ & $\mathbf{4 . 0}$ \\
\hline Fortuna & Panama & 1000 & 2251 & 300 & 4.3 \\
\hline Playas & Colombia & 1100 & 1663 & 204 & 3.6 \\
\hline Chivor (La Emeralda) & Colombia & 1200 & 1607 & 1008 & 1.7 \\
\hline Kulekhani & Nepal & 2000 & 1574 & 60 & 47.0 \\
\hline
\end{tabular}


The aggregated blue water footprint of the 35 selected hydropower plants is found to be $90 \mathrm{Gm}^{3} / y$, [3]. Analysis done for US hydroelectricity revealed that it consumes a gross estimated $11 \mathrm{~m}^{3} / \mathrm{GJ}$ from reservoir evaporation, [48].

It isn't found any study regarding the WF of reservoirs in Romania, but the results for Vidraru are similar with those obtained by other authors. However, it should be noticed that meteorological data used in this paper for assessment of WF of reservoir are based on a history meteorological archive that contains weather simulations.

\section{Conclusions}

Water-energy nexus is significantly studied and debated. Some scientists argue that hydroelectric generation is a significant water consumer, some disagree this idea. There are many studies regarding water consumption from hydropower that use different methodological approaches. The WF of a hydropower plant is based on the phenomenon of evaporation in the reservoir. As can be seen from the data and the results presented in this paper, the amount of water evaporated of the lake for one year is significant. But, there isn't a worldwide standard for estimating the evaporation in a reservoir and applying different methodologies leads to various results. On the other hand, since the reservoir has multiple purposes WF of the reservoir should be allocated to all its purposes. This is a real challenge, especially because of the lack of data. Therefore it is a need of correlating researches in this field to elaborate a standardized method to assess WF.

\section{References}

1. X. Luana, P. Wu, S. Sun, Y. Wang, X. Gao, Ecol. Indic., 89, 1-10, (2018)

2. A.Y. Hoekstra, P.Q. Hung, Virtual water trade: $A$ quantification of virtual water flows between nations in relation to international crop trade. Value of Water Research Report Series No. 11, UNESCO-IHE Institute for Water Education, Delft, The Netherlands, (2002), online at: http://www.waterfootprint.org/Reports/Report11.p $\underline{\mathrm{df}}$

3. A. Y. Hoekstra, A. K. Chapagain, M. M. Aldaya, M. M. Mekonnen, The water footprint assessment manual, Setting the global standard, Earthscan, London, UK, 2011

4. M. M. Mekonnen, A. Y. Hoekstra, The water footprint of electricity from hydropower, Hydrol. Earth Syst. Sci. 16, 179-187, (2012)

5. World Energy Outlook 2017, https://www.iea.org/weo2017/

6. V. K. Singh, S.K. Singal, Renew. Sust. Energ. Rev., 69, 610-619 (2017)

7. H. S. Sachdev, A. K. Akella, N. Kumar, Renew. Sust. Energ. Rev., 51, 1013-1022 (2015)

8. A. Evans, V. Strezov, T. J. Evans, Renew. Sust. Energ. Rev., 13, 1082-1088, (2009)
9. https://www.iea.org/statistics/statisticssearch/repo $\underline{\mathrm{rt} / \text { ?year}=2015 \& \text { country }=\text { Romania\&product }=\text { Elect }}$ ricityandHeat

10. http://www.hidroelectrica.ro/etichete/eticheta2017 ro.jpg

11. World Energy Council, World energy resources. Hydropower, on line at https://www.worldenergy.org/wpcontent/uploads/2017/03/WEResources_Hydropo wer 2016.pdf, (2016)

12. International Hydropower Association, Hydropower status report, online at: https://www.hydropower.org/publications/2018hydropower-status-report, (2018)

13. International Energy Agency, Renewable Energy Essentials: Hydropower, online at: https://www.iea.org/publications/freepublications/ publication/hydropower_essentials.pdf, (2010)

14. International Energy Agency, Update of Recommendations for Hydropower and the Environment, online at : https://www.ieahydro.org/media/0f1dda33/FinalA nnexXII Task2 BriefingDocument Oct2010.pdf, (2010)

15. Guidance on the requirements for hydropower in relation to Natura 2000, online at : http://ec.europa.eu/environment/nature/natura200 0/management/docs/Hydro $\% 20$ final $\% 20 \mathrm{May} \% 20$ 2018.final.pdf, (2018)

16. P.A. Torcellini, N. Long, R. Judkoff,. Consumptive Water Use for US Power Production, NREL, USA, online at: https://www.nrel.gov/docs/fy04osti/33905.pdf, (2003)

17. P.W. Gerbens-Leenes, A.Y. Hoekstra, T. van der Meer, T., Ecol. Econ., 68, 1052-1060, (2009)

18. M.M. Mekonnen, P.W. Gerbens - Leenes, A.Y. Hoekstra, Env. Sci., 1, 285-297, (2015)

19. I. Herath, M. Deurer, D. Horne, D., R. Singh, B. Clothier, J. Clean. Product., 19, 1582-1589, (2011)

20. T. H. Bakken, I. S. Modahl, K. Engeland, H. L. Raadal, S. Arnøy, J. Clean. Product., 113, 241250, (2016)

21. A. Tremblay, S. Tardif, I. B. Strachan, C. Turpin, Studying net evaporation from the Eastman -1 reservoir, Hydro Review, online at: http://www.hydroquebec.com/data/developpemen t-durable/pdf/studying-net-evaporation-eastmain1-reservoir.pdf, (2014)

22. L. Scherer, S. Pfister, Global water footprint assessment of hydropower, Renew. Energy, 99, 711-720, (2016)

23. A. Y. Hoekstra, Water Resour. Manag., 31, DOI 10.1007/s11269-017-1618-5, 3061-3081, (2017)

24. http://www.icoldcigb.net/GB/world register/general synthesis.asp

25. D. Zhao, J. Liu, Phys. Chem. Earth, 79-82, 4046, (2015) 
26. R. J. Hogeboom, L. Knook, A. Y. Hoekstra, Adv. Water Resour., 113, pp. 285-294, (2018)

27. http://www.hidroelectrica.ro/Details.aspx?page $=8$ 4\&article $=86$

28. D. M. Bucur, C.I. Cosoiu, R. G. Iovanel, A. A. Nicolae' S. C. Georgescu, Energy Procedia, 112, 51-57, (2017)

29. T. H. Bakken, Å. Killingtveit, K. Engeland, K. Alfredsen, A. Harby, Hydrol. Earth Syst. Sci., 17, 3983-4000, online at: www.hydrol-earth-systsci.net/17/3983/2013/, (2013)

30. M. M. Mekonnen, A.Y. Hoekstra, The water footprint of electricity from hydropower, Value of water research report series No. 51, UNESCOIHE Institute for Water Education, online at : http://waterfootprint.org/media/downloads/Report 51-WaterFootprintHydropower 1.pdf, (2011)

31. http://www.meteoblue.com (https://www.meteoblue.com/en/weather/forecast/ archive/vidraru-

dam_romania_7284201? fcstlength $=1$ m\&year $=20$ 17\&month=4)

32. http://www.meteoromania.ro/anm2/clima/monitori zare-climatica

33. http://www.dpcalc.org

34. T. H. Bakken, Å. Killingtveit, K. Alfredsen, Global Chall., 1, issue 5, 1600018, https://onlinelibrary.wiley.com/doi/epdf/10.1002/ gch2.201600018, (2017)

35. N. P. A. Vieira; E. de Oliveira Bueno; S Bueno Pereira; C. R. de Mello, Rev. Ambient. Água, 13, no. 3, e2134 - Taubaté, (2018)

36. E. R. C. Reynolds, F. B. Thompson, Forests, Climate, and Hydrology. Regional Impacts, United Nations University Press, ISBN 92-8080635-1, Tokyo, Japan, http://archive.unu.edu/unupress/unupbooks/80635 e/80635E00.htm\#Contents, (1988)

37. T. A. McMahon, M. C. Peel, L. Lowe, R. Srikanthan, and T. R. McVicar, Hydrol. Earth Syst. Sci., 17, 1331-1363, (2013)
38. D. Scradeanu, A. Gheorghe, Hidrogeologie generala, online at: http://old.unibuc.ro/prof/scradeanu_d/hidrO/docs/ 2014/dec/18 13 00 37hggg.pdf

39. C. D. Coelho, D.D. da Silva, G. C. Sediyama, M.C. Moreira, S. B. Pereira, A. M. Quintão Lana, J. Clean. Product., 153, 164-175, (2017)

40. I. Herath, M. Deurer, D. Horne, R. Singh, B. Clothier, The water footprint of hydroelectricity: a methodological comparison from a case study in New Zealand, J. Clean. Product., 19, 15821589, (2011)

41. P.W. Gerbens-Leenesa, A.Y. Hoekstra, R. Bosman, The blue and grey water footprint of construction materials: Steel, cement and glass, Water Resour. Ind., 19, 1-12, (2018)

42. K. Wärmark, Assessment of water footprint for civil construction projects, Master thesis, Uppsala University, online at : http://www.wprogram.nu/filer/exjobb/Katarina $\mathrm{W} \% \mathrm{C} 3 \% \mathrm{~A} 4 \mathrm{rm}$ ark.pdf, (2015)

43. https://ec.europa.eu/eurostat/statisticsexplained/index.php/Electricity price statistics

44. http://www.economica.net/bucurestiul-depasestepragul-de-2-milioane-de-turisti-dar-ramanecorijent-la-promovare-hotelieri_148910.html

45. https://www.lonelyplanet.com/romania/moneycosts

46. The risk analysis and measures plan identified at the Arges County, http://www.isuarges.ro/PAAR AG 2016.pdf, (2016)

47. G. Neculau, F.I. Stan, Evaporation and evapotranspiration in Romania, Forum geografic. Studii și cercetări de geografie și protecția mediului, XV, Supplementary Issue, pp. 39-48 http://dx.doi.org/10.5775/fg.2016.058.s, (2016)

48. E. A. Grubert, Adv. Water Resour., 96, 88-94, (2016) 